\title{
"The influence of the perceptions of institutional environment on entrepreneurial plans: exploring the moderating effects of firm age and firm size in Bulgarian enterprises"
}

\begin{tabular}{|c|c|}
\hline AUTHORS & $\begin{array}{l}\text { Zhelyu Vladimirov } \\
\text { Tzvetan Davidkov } \\
\text { Desislava Yordanova }\end{array}$ \\
\hline ARTICLE INFO & $\begin{array}{l}\text { Zhelyu Vladimirov, Tzvetan Davidkov and Desislava Yordanova (2017). The } \\
\text { influence of the perceptions of institutional environment on entrepreneurial plans: } \\
\text { exploring the moderating effects of firm age and firm size in Bulgarian } \\
\text { enterprises. Problems and Perspectives in Management, 15(1-1), 175-182. } \\
\text { doi:10.21511/ppm.15(1-1).2017.04 }\end{array}$ \\
\hline DOI & http://dx.doi.org/10.21511/ppm.15(1-1).2017.04 \\
\hline RELEASED ON & Wednesday, 10 May 2017 \\
\hline RECEIVED ON & Wednesday, 09 November 2016 \\
\hline ACCEPTED ON & Monday, 05 December 2016 \\
\hline LICENSE & $\begin{array}{l}(\mathrm{cc}) \text { EY-NC } \\
\text { This work is licensed under a Creative Commons Attribution-NonCommercial } 4.0 \\
\text { International License }\end{array}$ \\
\hline JOURNAL & "Problems and Perspectives in Management" \\
\hline ISSN PRINT & $1727-7051$ \\
\hline ISSN ONLINE & $1810-5467$ \\
\hline PUBLISHER & LLC "Consulting Publishing Company "Business Perspectives" \\
\hline FOUNDER & LLC "Consulting Publishing Company "Business Perspectives" \\
\hline
\end{tabular}

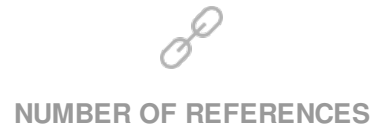

37
NUMBER OF FIGURES

0
NUMBER OF TABLES

2

(C) The author(s) 2022. This publication is an open access article. 


\title{
The influence of the perceptions of institutional environment on entrepreneurial plans: exploring the moderating effects of firm age and firm size in Bulgarian enterprises
}

\begin{abstract}
It was acknowledged that institutional environment plays an important role for shaping entrepreneurial behavior in transition economies. The present study investigates the influence of entrepreneurs' perceptions of institutional environment on their entrepreneurial plans in a large representative sample from a transition economy. The findings reveal that institutional environment has a significant influence on entrepreneurial plans and that firm age and size moderate the effect of institutional environment on entrepreneurial plans. The paper provides recommendations for future research and a discussion of practical implications.
\end{abstract}

Keywords: formal and informal institutions, entrepreneurial plans, moderating effects, Bulgaria.

JEL Classification: M19.

Received on: $9^{\text {th }}$ of November, 2016.

Accepted on: $5^{\text {th }}$ of December. 2016.

\section{Introduction}

During the last 25 years countries in Central and Eastern Europe (CEE) including Bulgaria experienced a transition from centrally planned to market economy, which was a complex process involving radical economic and political transformations (Dana and Ramadani, 2015). These transformations resulted in the establishment of liberal democracy and civic society, and prompted the emergence of a functioning market economy (Sokol, 2001). Entrepreneurship and private business is considered as an important factor for the successful transition to market economy (McMillan and Woodruff, 2002; Smallbone et al., 2001). The major obstacles to entrepreneurship development in transition countries were the legacy from the planned era and the lack of appropriate institutions (Dana and Ramadani, 2015; Estrin et al., 2006). Despite the steady economic growth in the recent past, Bulgaria still remains one of the least developed countries in the European Union. It is easier to do business in most EU member states than in Bulgaria (World Bank, 2014). In terms of Global Competitiveness Index, Bulgaria also lags behind the majority of the EU member states. Problematic factors for doing business include corruption, access to financing, inefficient government bureaucracy, policy instability, etc. (World Economic Forum, 2014). The transition was not completed even after the accession of Bulgaria to the European Union in 2007 (Trivić

(c) Zhelyu Vladimirov, Tzvetan Davidkov, Desislava Yordanova, 2017. Zhelyu Vladimirov, Professor, Faculty of Economics and Business Administration, Sofia University "St. Kliment Ohridski”, Bulgaria.

Tzvetan Davidkov, Professor, Faculty of Economics and Business Administration, Sofia University "St. Kliment Ohridski”, Bulgaria. Desislava Yordanova, Associate Professor, Faculty of Economics and Business Administration, Sofia University "St. Kliment Ohridski”, Bulgaria.

This is an Open Access article, distributed under the terms of the Creative Commons Attribution-NonCommercial 4.0 International license, which permits re-use, distribution, and reproduction, provided the materials aren't used for commercial purposes and the original work is properly cited. and Petković, 2015), which may be attributed to the fact that people's mindset adapts slower than regulatory reforms (Dana and Ramadani, 2015).

The contexts for entrepreneurship play important role for understanding this phenomenon providing opportunities and setting boundaries for individual actions (Welter, 2011). Previous qualitative research provides evidence that institutional environment may be an obstacle for the development of economically and socially productive entrepreneurship in transition economies such as Bulgaria (Williams and Volrey, 2015). Despite improvements in the past years, empirical findings from in-depth interviews with entrepreneurs suggest that institutional environment in a transition context may be especially challenging for entrepreneurs intending to grow their business (Williams and Volrey, 2015). However, it is difficult to generalize these qualitative research findings. There is a lack of large-scale representative studies examining how specific formal and informal institutions affect entrepreneurial plans in a transition context. The present research attempts to fill this gap by examining the influence of the entrepreneurs' perceptions of formal (legal framework) and informal institutions (attitudes of local authorities toward private business) on their entrepreneurial plans and the moderating effects of firm age and size on these relationships in a large representative sample of entrepreneurs from a transition economy. According to the theory of planned behavior goal intentions and implementation intentions defined as simple plans describing when, where, and how the behavior in question will occur are good predictors of behavior (Ajzen, 1991; Gollwitzer, 1999). In a transition context growth intentions and expansion plans, in particular, are found to be a good proxy measure of growth (Pistrui, 2003). As most entrepreneurial research has focused on past behavior (Kozan et al., 2006), and determinants of 
entrepreneurial behavior and performance are identified retrospectively, the investigation of determinants of entrepreneurial plans may contribute to understanding entrepreneurial behavior by providing a different perspective on the phenomenon of entrepreneurship.

The paper is structured as follows. The next section reviews previous theoretical and empirical contributions investigating the relationship between formal and informal institutions and entrepreneurial behavior and presents the hypotheses of the study. The second section describes the method for data collection, characteristics of the sample, the definition of dependent, independent, and control variables, and the methods for data analysis employed in the study. The following section presents the empirical findings of the present study. The final section outlines conclusions, limitations of the study and recommendations for future research.

\section{Literature review and hypotheses}

1.1. Formal and informal institutions. The Nobel Prize winner Douglass North is recognized as one of the founders of new institutional economics. In his seminal work "Institutions, Institutional Change and Economic Performance", North develops an analytical framework for explaining the ways in which institutions and institutional change affect the performance of economies, both at a given time and over time. North defines institutions as "the rules of the game in a society" and "the humanly devised constrains that shape human interaction" (North, 1990, p. 3). They may be created or evolving over time. North (1990) makes a distinction between formal and informal institutions and emphasizes that the differences between both types of institutions is one of degree. Institutions represent a continuum from traditions, customs, and taboos at one end to written laws at the other. The relationship between formal and informal institutions is unidirectional: formal rules tend to replace informal constraints.

Informal institutions include codes of conduct, norms of behavior, and conventions (North, 1990). They may be extensions, elaborations, and modifications of formal rules, socially sanctioned norms of behavior, or internally enforced standards of conduct. Informal rules are transmitted social information and form part of the culture in a society. Culture shapes the way in which informal constrains get specified and plays an important role in the way in which they evolve (North, 1990). The move from less to more complex societies is associated with less reliance on unwritten traditions and customs and with greater adoption of written laws due to increasing specialization and division of labor (North, 1990). Formal institutions comprise political and judicial rules, economic rules, and contracts (North, 1990). Political rules define the hierarchical struc- ture of the policy, its decision structure and agenda control, while economic rules define property rights, while contracts settle particular agreements in exchange (North, 1990). The hierarchy of formal rules defines constraints from general rules to particular specifications (North, 1990). It is headed by constitutions followed by statute and common laws, specific bylaws, and individual contracts. Formal rules may lower transaction costs and, thus, can complement and increase the effectiveness of informal constraints. North (1990) argues that formal institutions can be changed relatively easy with political or judicial decisions, while informal institutions are very resistant to change, because they are path-dependent and embedded in the culture of a society. Although formal institutions may be devised particularly to modify, revise, or replace informal constraints, the last may not change simultaneously in reaction to changes in formal institutions.

Further, North (1990) makes a distinction between institutions and organizations. Organizations comprise groups of individuals united by the common purpose to maximize wealth or income, or to achieve other objectives. Organizations include political, economic, and social bodies. Institutions and organizations are similar in that both provide a structure to human interaction. Organizations are created as a function of institutional constraints, technology, income, and preferences and reflect the opportunities generated by the institutional framework in a society. The institutional framework determines not only how organizations emerge but also how they evolve. In turn, organizations influence the evolution of the institutional framework in a society. The kinds of skills and knowledge fostered by the structure of an economy will shape the direction of change and gradually alter the institutional framework. North (1990) stresses that organizations and, in particular, entrepreneurial undertakings, in an attempt to accomplish their objectives become major agents of institutional change.

North (1990) argues that institutions perform various tasks in a society. The main role of institutions is to reduce uncertainty and provide stability in everyday life. They establish a stable structure to human interaction. Institutions comprise guidelines about what individuals are prohibited from doing as well as under what condition individuals are permitted to undertake certain activities. Institutions structure incentives in political, economic, or social exchange. They also affect the level of transaction and transformation (production) costs and facilitate economic exchange. Therefore, they are fundamental determinants of economic performance in the long run. Institutional development may lead to a pathdependent pattern of development. North (1990) indicates how institutional analysis must be incorporated into neo-classical theory and explores the po- 
tential for the construction of a dynamic theory of long-term economic change.

1.2. Formal and informal institutions and entrepreneurial behavior in a transition context. Institutional theory has been acknowledged to provide the most consistent and appropriate conceptual framework for examining the impact of environmental characteristics on entrepreneurship (Veciana, 1999). The dynamics of entrepreneurship depends on institutional environment (Acs et al., 2008). Entrepreneurship in transition economies has distinctive characteristics in comparison with mature market economies, which reflects "the unstable and often hostile nature of the external environment and the scarcity of certain key resources, particularly capital" (Smallbone and Welter, 2001, p. 260). Scase (1997) argues that in transition economies, most private businesses are "proprietors" (owning property for realizing profits, but not striving for capital accumulation) rather than "entrepreneurs" (striving for capital accumulation and business growth) because of the uncertainty describing these economies. Smallbone and Welter (2001) distinguish various specific forms of entrepreneurship in this context including small business ownership, informal sector entrepreneurship, and "nomenclatura" entrepreneurship ${ }^{1}$ Further, Smallbone and Welter (2006) describe examples of entrepreneurial behavior that may seem not optimal, but represent a rational response to specific institutional environment such as avoidance behavior; a high degree of networking; particular financial bootstrapping tactics; and diversification or portfolio entrepreneurship. In addition to differences between transition and mature economies, there are also differences among transition countries in relation to entrepreneurship, which are due to differences in starting conditions, the pace of reforms, and macroeconomic indicators (Smallbone and Welter, 2001). The nature of entrepreneurial opportunities in transition economies varies according to the country's stage of transition (Smallbone and Welter, 2006). In transition countries, where the framework conditions for market economy are still not well developed, there is a threat of development of unproductive or destructive forms of entrepreneurship (Smallbone and Welter, 2006).

The important role of the existing institutional framework in countries in transition for shaping entrepreneurial behavior and its economic contribution has been confirmed empirically (Welter et al., 2003). It was acknowledged that "institutions set boundaries for enterprise behavior" in transition countries (Welter et al., 2003, p. 248). Particularly, the distinctive role of formal and informal institutions for entrepre-

\footnotetext{
${ }^{1}$ This form of entrepreneurship is characterized by the use of political influence for acquiring resources or protecting market niches (Smallbone and Welter, 2001).
}

neurial behavior was highlighted: "formal institutions create opportunity fields for entrepreneurship; informal institutions determine the collective and individual perception of entrepreneurial opportunities" (Welter et al., 2003, p. 248). Informal constraints may become highly important in unstable or weakly structured environments, where formal rules often fail or are absent (Welter et al., 2003). Drawing on indepth interviews, Williams and Volrey (2015) demonstrate that an institutional environment characterized by "institutional asymmetry" between formal and informal institutions may influence negatively entrepreneurial behavior in a transition economy. The authors suggest that such an asymmetry in the institutional environment may be associated with low growth aspirations among entrepreneurs, rent-seeking activities, and involvement in informal activities and corruption. Therefore, we suggest that:

H1: Positive perceptions of legislation influence positively entrepreneurial plans.

H2: Positive perceptions of attitudes of local authorities toward private business influence positively entrepreneurial plans.

1.3. The moderating role of firm age and size. New and small firms face the problems of liabilities of newness (Stinchcombe, 1965; Hannan and Freeman, 1984) and smallness (Aldrich and Auster, 1986). These burdens present unique challenges for firm performance in new and small firms. External liabilities of newness such as lack of experience, technological barriers, lack of legitimacy, etc., "make mobilization and acquisition of resources difficult" (Aldrich and Auster, 1986, p. 178). New firms may also face internal obstacles associated with "the creation and clarification of roles and structures consistent with external constrains, and the ability to attract qualified employees" (Aldrich and Auster, 1986, p. 178). Younger firms often lack experience and, therefore, tend to rely on informal management systems and training practices (Cardon and Stevens, 2004). In addition, their lack of legitimacy within the industry is associated with difficulties to recruit employees (Cardon and Stevens, 2004). The positive perceptions of institutional environment may have disproportionately larger positive influence on entrepreneurial plans in older firms, because younger firms face relatively more internal and external obstacles and lack of legitimacy, which may impede them to formulate and undertake new plans despite their positive perceptions of institutional environment. Therefore, we suggest that:

H3: Firms age moderates the positive effect of the positive perceptions of legal framework on entrepreneurial plans, such that the relationship is stronger in older firms.

H4: Firms age moderates the positive effect of the positive perceptions of attitudes of local authorities 
toward private business on entrepreneurial plans, such that the relationship is stronger in older firms.

Liability of smallness implies problems in raising capital, observing tax laws and government regulations, competing for labor with larger organizations, recruiting and training employees (Aldrich and Auster, 1986). "The very size of small businesses creates a special condition - which can be referred to as resource poverty - that distinguishes them from their larger counterparts and requires some very different management approaches" (Welsh and White, 1981, p. 18). Resource poverty does not permit the adequate performance of certain activities within the company (Welsh and White, 1981), which may influence negatively firm performance. Despite their positive perceptions of institutional environment, smaller firms may be less likely to formulate and undertake new plans, because they dispose with fewer resources than larger firms. Therefore, we suggest that:

H5: Firms size moderates the positive effect of the positive perceptions of legal framework on entrepreneurial plans, such that the relationship is stronger in larger firms.

H6: Firms size moderates the positive effect of the attitudes of local authorities toward private business on entrepreneurial plans, such that the relationship is stronger in larger firms.

\section{Research methodology}

2.1. Sample and data collection. The survey conducted in 2011 included 1090 respondents. The data were collected through a survey using standardized interviews with one of the owner-managers of the companies. The survey covered a wide range of topics including demographic characteristics, motivation for start-up, psychological traits, values and attitudes, management style, management skills, support from family, perceptions of environment, entrepreneurial plans, firm age, firm size, initial resources, sector, legal form, etc. The survey was representative for the population of Bulgarian private enterprises with regard to legal form and location and was accurate to $0.05(5 \%)$. The characteristics of the respondents are presented in Table 1.

Table 1. Characteristics of the respondents

\begin{tabular}{|l|c|}
\hline \multicolumn{1}{|c|}{ Characteristics } & $\%$ \\
\hline Gender & 55 \\
\hline$\quad$ Male & 45 \\
\hline Age Female & 5 \\
\hline$\quad$ Up to 30 years old & 25 \\
\hline$\quad 31$ to 40 years old & 33 \\
\hline$\quad 41$ to 50 years old & 28 \\
\hline$\quad 51$ to 60 years old & 9 \\
\hline$\quad$ Over 60 years old & \\
\hline
\end{tabular}

\begin{tabular}{|ll|c|}
\hline Education & \\
\hline - & Primary education \& Basic education & 1 \\
\hline - Secondary education & 39 \\
\hline - & Higher education and above - specializations, doctoral degrees & 6 \\
\hline
\end{tabular}

2.2. Variables. The dependent variable in this study is PLANS. The binary variable PLANS takes value 1 if the entrepreneur plans to expand ones current business and value 0 otherwise.

Several independent variables are included in the study. The variable LEGAL indicates whether the entrepreneur perceives the legal framework as very good or relatively good (value 1) or not (value 0 ). The variable ATTITUDES reveals whether the entrepreneur perceives the attitudes of local authorities toward private business as positive and supportive (value 1) or not (value 0). The variable FIRM_AGE indicates the age of the company in number of years. It is mean-centered in order to avoid multicollinearity problems. The variable SIZE is a dummy variable with value 1 if the company has less than 11 employees and value 0 otherwise.

Two industry dummy variables are employed in the study. SERVICES is a binary variable, which takes value 1 if the company operates mainly in the service sector and value 0 if it operates predominantly in another sector. MANUFACTURING reveals if the company operates mainly in the manufacturing sector (value 1) or in another sector (value 0 ).

2.3. Data analysis. Taking into account the objectives of this study and the properties of the data, we employ a binary logistic regression to test the proposed hypotheses. A binary logistic regression was employed to deal explicitly with the dependent variable PLANS, which is binary (Greene, 1997). For the estimated models, the modelling assumptions were satisfied. The VIF values are around 4 . The logistic regression is a robust method, since, according to Greene (1997):

- the dependent variable needs not to be normally distributed;

- logistic regression does not assume a linear relationship between the dependent and the independent variables;

- the dependent variable needs not to be homoscedastic for each level of the independent variable(s);

- normally distributed error terms are not assumed;

- independent variables can be categorical;

- it does not require independent variables to be interval or unbounded.

The application of non-parametric techniques is adequate when the independent variables are predominantly categorical. The use of the maximum likelihood approach is recommended when sample selection bias is possible (Nawata, 1994). Binary logistic 
regression provides a framework that indicates if and how well independent variables can adequately predict the dependent variable. The research hypotheses will be supported if regression analysis provides an acceptable accuracy of classification of cases and of goodness of fit measures. In addition, the impact of explanatory variables should be statistically significant at least at the 10 percent level (two-tailed test) with the predicted sign. Wald statistics will be used to estimate the significance of the independent variables. Data analyses are performed with the statistical package SPSS version 15.0.

A moderator is a variable that influences the relationship between two variables (Baron and Kenny, 1986). The existence of a moderating effect implies that the casual relationship between two variables depends on the moderator (Baron and Kenny, 1986). In order to test for the presence of moderating effects of firm age and size on the relationship between the perceptions of institutional environment and entrepreneurial plans interaction terms were calculated by multiplying LEGAL and ATTITUDES with FIRM AGE and SIZE. The continuous variable FIRM_AGE was mean-centered before multiplying it to avoid multicollinearity problems (Aiken and West, 1991).

\section{Empirical findings}

Table 1 contains the results of a binary logistic regression analysis in which the dependent variable PLANS is regressed on the independent variables LEGAL, ATTITUDES, FIRM AGE, and SIZE; the interaction terms LEGAL $x$ FIRM_AGE, LEGAL $x$ SIZE, ATTITUDES $x$ FIR M_AGE, and ATTITUDES $x$ SIZE; and the control variables MANUFACTURING and SERVICES. As demonstrated in Table 1, the model is significant at $99 \%$ confidence level according to Chi-square statistics. Therefore, the null hypothesis that all coefficients (except the constant) are zero can be rejected. The overall predictive ability of the model to classify correctly family businesses is $58.9 \%$. The variables ATTITUDES and MANUFACTURING have a strong positive effect on the dependent variable $(p<$ 0.05 ). Entrepreneurs who perceive the attitudes of local authorities toward private business as positive and supportive are more likely to report plans for expanding their current activities. Hypothesis H2 cannot be rejected. Entrepreneurs operating in manufacturing businesses are also more likely to exhibit entrepreneurial plans. The variables SIZE and FIRM_AGE are significantly and negatively associated with PLANS. Entrepreneurs in older enterprises and in enterprises with less than 11 employees are less likely to plan for expansion of the current business activities. The variables LEGAL and SERVICES do not exert a statistically significant effect on the dependent variable PLANS. Hypothesis $\mathrm{H} 1$ can be rejected. The interaction term ATTITUDES x FIRM_AGE has a statistically signif- icant positive impact $(\mathrm{p}<0.05)$ on PLANS, thus granting support to Hypothesis 4 and suggesting that with increasing the firm age the probability of reporting entrepreneurial plans is higher for entrepreneurs, who perceive the attitudes of local authorities toward private business as positive and supportive. The interaction term LEGAL $x$ FIRM_AGE shows a significant and positive effect on the dependent variable ( $p$ $<0.05$ ), implying that with increasing the firm age the probability of reporting entrepreneurial plans is higher for entrepreneurs who perceives the legal framework as very good or relatively good. Hypothesis H3 cannot be rejected. Contrary to our expectations, the interaction variables ATTITUDES x SIZE and LEGAL x SIZE tend to exhibit insignificant effect on the dependent PLANS. Hypotheses H5 and H6 can be rejected.

Table 2. Results from a binary logistic regression $($ dependent variable $=$ PLANS $)$.

\begin{tabular}{|l|c|c|c|}
\hline \multicolumn{1}{|c|}{ Variables } & Coefficients & Std. error & Wald \\
\hline ATTITUDES & $0.600^{\star \star}$ & 0.305 & 3.862 \\
\hline LEGAL & -0.143 & 0.259 & 0.305 \\
\hline FIRM_AGE & $-0.020^{*}$ & 0.011 & 3.578 \\
\hline SIZE & $-0.543^{\star \star}$ & 0.213 & 6.469 \\
\hline MANUFACTURING & $0.463^{* \star *}$ & 0.178 & 6.771 \\
\hline SERVICES & 0.184 & 0.147 & 1.578 \\
\hline ATTITUDE x FIRM_AGE & $0.045^{\star \star}$ & 0.020 & 5.110 \\
\hline ATTITUDE x SIZE & -0.474 & 0.392 & 1.466 \\
\hline LEGAL x FIRM_AGE & $0.038^{\star \star}$ & 0.015 & 6.227 \\
\hline LEGAL x SIZE & 0.294 & 0.315 & 0.871 \\
\hline Constant & -0.078 & 0.209 & 0.138 \\
\hline & & & \\
\hline Chi-square & $43.62^{* \star *}$ & & \\
\hline -2 Log likelihood & 1411.63 & & \\
\hline Overall \% correct predictions & $58.9 \%$ & & \\
\hline
\end{tabular}

Note: 1$) * \mathrm{p}<0.1 * * \mathrm{p}<0.05 * * * \mathrm{p}<0.01$

\section{Discussion and conclusions}

Bhat and Khan (2014, p. 85) reveal that contextual environment is considered to be more central in the entrepreneurship development of any economy. Among the macro or external factors, the institutional environment has a significant impact on the entrepreneurship process. A great number of studies confirm that countries with better institutions have higher rates of growth than countries with poor institutions (North, 1991; Henrekson, 2007). Researchers demonstrated also that the entrepreneurial environment includes arrangements with institutions and the role of the government (Rodrik, 2007). For example, Kayne (1999, p. 2) shows that "states through their laws, regulations, investments, and programs - have considerable impact on where entrepreneurs choose to establish new enterprises and the probability that those enterprises will succeed". There are, however, few researches on the institutions as an important component of the environment for entrepreneurial plans, especially in transition and 
developing countries. According to Van de Ven (1993) studies that focus exclusively on the characteristics and behavior of entrepreneurs are deficient without considering the environment. Therefore, this paper contributes to the small number of empirical research on the effects of institutional environment on entrepreneurship development.

The main findings reveal that the informal institutions in term of positive local administration ATTITUDES influence positively and significantly entrepreneurial plans for expansion. In difference to that, the perception of formal institutions in the form of LEGAL environment have negative, but not significant, associations with entrepreneurial growth plans. This can be explained by the fact that compared to the period before the country memberships in the EU (Vladimirov, 2001) or to the first years of this memberships (ESTAT Agency, 2009), the recent years data witness a relative stabilization of the institutional environment. For example, at the beginning of 2011 the prevailing share of entrepreneurs evaluate most of the business environment elements as neutral (not favorable, neither unfavorable). The environment is unfavorable for a small number of them, while it is perceived as favorable by quite a greater share (Simeonova-Ganeva et al., 2012). The institutional environment seems more favorable for greater size enterprises, from smaller locations, and for entrepreneurs with lower educational level. Contrary to that, the environment seems less favorable for micro-enterprises, from bigger locations, and for entrepreneurs with higher level of education (Simeonova-Ganeva et al., 2012). Generally, the SME operating in the manufacturing sector perceive the environment as more favorable, which is in line with the data of the present study.

Important factors for the entrepreneurial growth plans are firm age and firm size. As the present data show older firms in general are less likely to have expansion plans, while older firms which have positive perceptions of the legal and attitudinal environment have a greater propensity to undertake expansion plans. These data confirm the important role of formal and informal institutions for the entrepreneurial plans. Contrary to our hypotheses, however, the firm size does not moderate the effects of local administration attitudes and legal environment on the entrepreneurial plans.
Although the present study is based on a large representative sample of Bulgarian private enterprises, the research reported in this paper has several limitations. First, data were collected through self-reported survey and thus may be subject to cognitive and motivational biases and errors. The fact that the survey was anonymous may lessen some areas of potential biases. Second, our ability to draw causal inferences is limited by the cross-sectional nature of the data. Third, the conclusions of our investigation are limited by the geographical representation of the study. Therefore, our results may not be applicable to non-transition countries due to cultural, economic, political, and institutional differences. And finally, our findings may be influenced by the cultural environment and therefore may not be applicable to other transition economies.

In order to enhance the understanding of the influence of the institutional environment on growth aspirations and actual growth in companies operating in a transition context, future research needs to examine the following aspects. First, future research should examine the effects of other institutional factors posited by theoretical and empirical literature as affecting entrepreneurial behavior, which are not included in this study. Second, future research should also examine to what extent the findings of this study can be generalized to firms in other transitional countries. And finally, a longitudinal analysis should complement the findings in this research in order to confirm causal relationships.

These findings have important implications for policy makers and investors. Loan institutions, risk capitalists, and business angels trying to identify growth oriented businesses in a transition context should pay more attention to firm characteristics such as age and size. Policy makers should be aware that in transition economies growth intentions and expansion plans, in particular, may be a good proxy measure of growth (Pistrui, 2003; Ajzen, 1991; Gollwitzer, 1999). Institutional environment has a significant influence on the formation of expansion plans among private businesses in such a context, therefore, formal and informal institutions should be at the focus of attention of policy makers in order to stimulate growth in some sectors and the economy as a whole. Policy makers should also be aware that institutional factors have differential effects on expansion plans in new and established organizations.

\section{References}

1. Acs, Z. J., Desai, S. and Hessels, J. (2008). Entrepreneurship, economic development and institutions, Small Business Economics, 31 (2-3), 219-234.

2. Aiken, L.S. and West, S.G. (1991). Multiple regression: Testing and interpreting interactions. Thousand Oaks, CA: Sage.

3. Ajzen, I. (1991). Theory of planned behavior, Organizational Behavior and Human Decision Processes, 50 (2), 179-211.

4. Aldrich, H. and Auster, E. (1986). Even dwarfs started small: Liabilities of age and size and their strategic implications, Research in Organizational Behavior, 8, 165-198.

5. Bhat, S. and Khan, R. (2014). Entrepreneurship and Institutional Environment: Perspectives from the Review of 
Literature, European Journal of Business and Management, 6 (1), 84-91.

6. Cardon, M. and Stevens, C. (2004). Managing human resources in small organizations: What do we know? Human Resource Management Review, 14, 295-303.

7. Dana, L.P. and Ramadani, V. (2015). Context and Uniqueness of Transition Economies. In Dana, L.P. and Ramadani, V. (eds.) Family Businesses in Transition Economies. Springer International Publishing. 39-69

8. ESTAT Agency. (2009). Index of Business Climate, 2002-2008.

9. Estrin, S., Meyer, K.E. and Bytchkova, M. (2006). Entrepreneurship in transition economies, in Casson, M., Yeung, B., Basu, A. and Wadeson (eds.) The Oxford Handbook of Entrepreneurship. Oxford: Oxford University Press, 693-725.

10. Gollwitzer, P.M. (1999). Implementation intentions: Strong effects of simple plans, American Psychologist, 54 (7), 493-503.

11. Greene, W. (1997). Econometric analysis. $3^{\text {rd }}$ ed. New Jersey: Prentice-Hall International.

12. Hannan, M. and Freeman, J. (1984). Structural inertia and organizational change, American Journal of Sociology, 49 (2), 149-164.

13. Henrekson, M. (2007). Entrepreneurship and Institutions, IFN Working Paper No. 707, 2007, Stockholm. Available at: www.ifn.se. Accessed on $25^{\text {th }}$ September, 2016.

14. Kayne, J. (1999). State Entrepreneurship Policies and Programs, Kauffman Center for Entrepreneurial Leadership, Ewing Marion Kauffman Foundation.

15. Kozan, M., Oksoy, D. and Ozsoy, O. (2006). Growth plans of small businesses in Turkey: Individual and environmental influences, Journal of Small Business Management, 44 (1), 114-129.

16. McMillan, J. and Woodruff, C. (2002). The central role of entrepreneurs in transition economies, Journal of Economic Perspectives, 1693, 153-170.

17. Nawata, K. (1994). Estimation of sample selection bias models by the maximum likelihood estimator and Heckman's two-step estimator, Economics Letters, 45 (1), 33-40.

18. North, D. (1990). Institutions, Institutional Change and Economic Performance. Cambridge: Cambridge University Press.

19. North, D. (1991). Institutions, Journal of Economic Perspectives, 5 (1), 97-112.

20. Pistrui, D. (2003). Growth intentions and expansion plans of new entrepreneurs in transitioning economies: An investigation into family dynamics, entrepreneurship and enterprise development, Doctoral dissertation, Universitat Autonóma de Barcelona.

21. Rodrik, D. (2007). One Economics, Many Recipes: Globalization, Institutions and Economic Growth. Princeton and Oxford: Princeton University Press.

22. Scase, R. (1997). The role of small businesses in the economic transformation of Eastern Europe: real but relatively unimportant, International Small Business Journal, 16, 113-121.

23. Simeonova-Ganeva, R., Vladimirov, Z., Ganev, K., Panayotova, N., Dimitrova, T., Yordanova, D., Boeva, M., Kulev, D., Peneva, R. and Todorova, M. (2012). Analysis of the Situation and Factors for Development of SMEs in Bulgaria 2011-2012: Economic Recovery and Competitiveness, Bulgarian Small and Medium Enterprises Promotion Agency, Ministry of Economy, Energy and Tourism, Noema, Sofia.

24. Smallbone, D. and Welter, F. (2001). The distinctiveness of entrepreneurship in transition economies, Small Business Economics, 16 (4), 249-262.

25. Smallbone, D. and Welter, F. (2006). Conceptualizing entrepreneurship in a transition context, International Journal of Entrepreneurship and Small Business, 3 (2), 190-206.

26. Sokol, M. (2001). Central and Eastern Europe a decade after the fall of state-socialism: Regional dimensions of transition processes, Regional Studies, 35 (7), 645-655.

27. Stinchcombe, A. (1965). Social structure and organizations, in J.G. March (ed.) Handbook of organizations, Rand McNally: Chicago, 142-193.

28. Trivić, J. and Petković, S. (2015). Different Features of Transition Economies: Institutions Matter, in Dana and L.P., Ramadani, V. (eds.) Family Businesses in Transition Economies, Springer International Publishing. pp. 71-96

29. Van de Ven, A.H. (1993). The development of an infrastructure for entrepreneurship, Journal of Business Venturing, 211-230.

30. Veciana, J.M. (1999). Creación de empresas como programa de investigación científica, Revista Europea de Dirección y Economía de la Empresa, 8 (3), 11-36.

31. Vladimirov, Z. (2001). Is there well-functioning market economy in Bulgaria? In: European dimensions in the governance and economy of transition countries. Sofia University "St. Kliment Ohridski", Faculty of Economics and Business Administration. Publishing house "Paradigma", 176-198, Sofia.

32. Welsh, J. and White, J. (1981). A small business is not a little big business, Harvard Business Review, pp. 18-32.

33. Welter, F. (2011). Contextualizing entrepreneurship-conceptual challenges and ways forward, Entrepreneurship Theory and Practice, 35 (1), 165-184.

34. Welter, F., Smallbone, D., Aculai, E., Isakova, N. and Schakirova, N. (2003). Female Entrepreneurship in Post Soviet Countries, in Butler, J. (ed.) New Perspectives on Women Entrepreneurs, Information Age, Greenwich, pp. 243-269. 
35. Williams, N. and Vorley, T. (2015). Institutional asymmetry: how formal and informal institutions affect entrepreneurship in Bulgaria. International Small Business Journal, 33 (8), pp. 840-861.

36. World Bank. (2014). Doing Business 2015: Going Beyond Efficiency. Washington, DC: World Bank.

37. World Economic Forum. (2014). Global Competitiveness Report 2014-2015. WEF, Switzerland. 